\title{
KOSTEN WIEDER REINHOLEN
}

Liebe Leserin, lieber Leser,

seit Anfang des Jahres gelten für Motoren mit Leistungen von 130 bis $560 \mathrm{~kW}$ die Abgasgrenzwerte gemäß EG 97/86 Stufe IV beziehungsweise Tier 4 final. Eine große Herausforderung für die Motoren- und Abgasanlagenhersteller war dabei die drastische Reduzierung der bis dato geltenden Ruß- und $\mathrm{NO}_{\mathrm{x}}{ }^{-}$ Emissionen. Dies erfordert eine umfangreiche Abgasnachbehandlung - bei gleichzeitig gefordertem konstanten oder besser reduzierten Kraftstoffverbrauch. Diese Herausforderung wurde von den Konstrukteuren und Entwicklern mit Bravour gemeistert. Oftmals wurde die Entwicklung der neuen Motorenbaureihen dabei auch genutzt, um das Produktportfolio abzurunden.

So stellt beispielsweise Liebherr in dieser Ausgabe den neuen Vierzylinder-Reihendieselmotor D944 für den Leistungsbereich zwischen 200 und $230 \mathrm{~kW}$ vor. Der neue Motor entstand durch die konsequente Nutzung des bestehenden Motorenbaukastens ergänzt durch zahlreiche Neuentwicklungen. So wurde zum Beispiel die Zylindereinheit des Sechszylindermotors mit vergrößerter Zylinderbohrung übernommen, der vordere Aggregateträger (Frontend) dagegen überarbeitet.

Unbestritten ist, dass mit der Begrenzung der Abgasemissionen ein großer Schritt bezüglich Gesundheits- und Umweltschutz getan wurde. Unbestritten ist aber auch, dass die Entwicklung und der Einsatz der hierfür erforderlichen Komponenten wie DOC, DPF und SCR sehr kostenintensiv sind. So veranschaulicht der Beitrag von Still unter anderem wie sich die Kosten für Verbrennungsmotor, Luftansaugung, Abgasstrecke und Kühlung für einen Dieselstapler gegenüber der Vorgängerversion erhöhen.

Kaum sind die neuen Emissionsrichtlinien in Kraft, wird über neue Grenzwerte unter anderem auch für CO diskutiert. So wichtig Umweltschutz ist, man darf die Hersteller aber nicht überfordern. Die Kosten für die Entwicklung neuer Systeme, um Abgasemissionsrichtlinien zu erfüllen, müssen erst einmal wieder erwirtschaftet werden, bevor an eine weitere Verschärfung gedacht werden kann.

Ihr

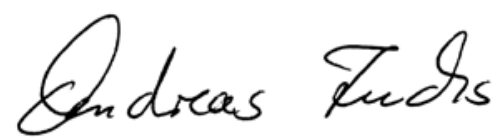

ANDREAS FUCHS, Chefkorrespondent Hochheim, 20. März 2014

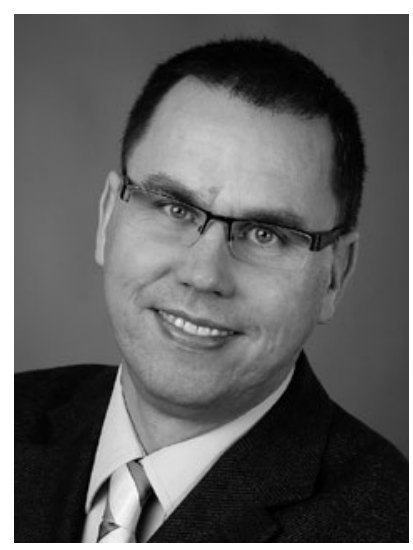

\section{RECUPERATING COSTS}

Dear Reader

At the beginning of this year, the 97/86/EC Stage IV and Tier 4 final emissions standards came into force for engines with power outputs of 130 to $560 \mathrm{~kW}$. A major challenge for engine and exhaust system manufacturers was the drastic reduction in the previous PM and $\mathrm{NO}_{\mathrm{x}}$ emission limits. This requires extensive exhaust aftertreatment - while at the same time fulfilling the need to keep fuel consumption constant or, in an ideal case, even to reduce it. This challenge has been brilliantly met by designers and developers. In many cases, the development of the new engine series has also been used to round off the product portfolio.

For example, in this issue Liebherr presents its new D944 inline four-cylinder diesel engine for the power range between 200 and $230 \mathrm{~kW}$. The new engine was built by consistently using the existing modular engine system and supplementing it with numerous new developments. For instance, it adopts the cylinder unit of the six-cylinder engine with an increased cylinder bore, whereas the front-end components have been modified.

There is no doubt that the limitation of exhaust emissions has been a major step forward in protecting health and the environment. But it is also clear that the development and application of the components required to achieve this, such as DOC, DPF and SCR, are very cost-intensive. The report by Still, for example, shows among other things how the costs of the engine as well as the air intake, exhaust and cooling systems for a diesel forklift have risen compared to the predecessor version.

No sooner have the new emissions standards been introduced, than discussions are already taking place concerning new limits, among other things also for CO. But manufacturers should be given the chance to recuperate the costs of developing new systems for meeting existing emissions standards before efforts are made to tighten them even further.

Best regards, 